\title{
Improving the flow of diagnostic information
}

\section{The importance of STARD for authors and readers}

\author{
Robert G. Holloway, MD, MPH
}

Neurology has adopted the Standards for Reporting of Diagnostic Accuracy (STARD) initiative. ${ }^{1}$ The STARD Steering Committee and Working Group has published a checklist and a prototypical flow diagram to help authors describe the design, execution, analysis, interpretation, and implications of research on diagnostic tests (see the Neurology Web site, www.Neurology.org). ${ }^{2}$ The STARD initiative, to improve the quality of reporting of diagnostic studies, is long overdue and follows the success of the CONSORT initiative, published in 1996 and updated in 2001 , to improve the reporting of clinical trials. ${ }^{3}$

The need for STARD is clear. The methodological quality of studies of diagnostic accuracy is often poor, making judgments about validity, bias, and applicability to patients in clinical settings difficult. ${ }^{4}$ Studies of diagnostic accuracy in the neurologic literature are no exception. ${ }^{5,6}$ Such misinformation can lead to both test overuse, increasing patient risk and costs, and to test underuse, missing opportunities to improve health. The hope of the STARD initiative is to improve the quality of reported studies and to standardize information flow to optimize the use of both established and novel diagnostic tests.

The list of neurologic tests and technologies needing assessment is long and growing longer: neurologic examination findings, neuroimaging studies, neurophysiologic studies, auto-antibody tests, blood, tissue, and genetic markers, and many others. In addition, studies of diagnostic accuracy will be needed for biomarkers, functional imaging studies, proteomics and gene expression profiling. ${ }^{7}$ This research will provide clues about disease pathogenesis and risk factors, and better insights into disease diagnosis, prognosis, and novel therapies. The usefulness of these studies, however, depends upon "translational" research-translating these basic sci-

Additional material related to this article can be found on the Neurology Web site. Go to www.neurology.org and scroll down the Table of Contents for the September 9 issue to find the link for this article. ence advances into applied and tangible improvement in health and disease. In many cases, the research "language," which will allow the basic science community to communicate with the clinical researchers, and the clinical researchers to communicate with health care providers and patients, will be the study designs of diagnostic accuracy. Whether they be imaging biomarkers, serum markers, or the complex, mind-numbing possibilities of microassays to assess gene expression profiling, many of the advances embedded in this information will arise from the study design and basic research elements articulated by STARD.

Most issues of Neurology have articles reporting studies of diagnostic accuracy: two in the May 13th issue and three in May 27th issue. Neurology authors should complete the 25-item STARD checklist when submitting a study of diagnostic accuracy. This checklist will standardize information about study design, conduct and analysis to allow a reader to judge the presence and magnitude of bias. Authors should also submit a flow diagram explaining the study design, sampling procedures, and the timing and results of the index test and reference standard, as such details are often difficult to interpret in the narrative.

A particularly important aspect of STARD is the explanation and elaboration document, a comprehensive guide clarifying the meaning, rationale and optimal use of each item on the checklist. ${ }^{8}$ Researchers will find STARD, including the explanation document, useful both in preparing research for journal submission and in planning new studies of diagnostic accuracy. Peer reviewers will find STARD helpful in their critical appraisal and feedback for authors.

The STARD initiative will be a learning process for all-authors, readers, peer reviewers, and editors-who are currently more familiar with the study designs to evaluate new therapies (e.g., randomized controlled trials). The ultimate success of the STARD initiative however, will depend on the

From the Departments of Neurology and Community and Preventive Medicine, University of Rochester, Rochester, NY.

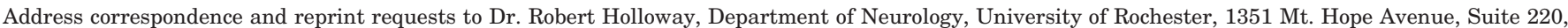
Rochester, NY 14620; e-mail: Robert.Holloway@ctcc.rochester.edu 
collaboration of basic scientists, clinical researchers, peer reviewers, journal editors and health care providers. The field of diagnostic technology assessment continues to mature, and better reporting of diagnostic information has the promise to improve the efficiency and quality of neurologic care.

\section{References}

1. Information for Authors. Neurology. Available at: http://www.neurology. org/misc/ifora.shtml. Accessed July 7, 2003.
2. Bossuyt PM, Reitsma JB, Bruns DE, et al. for the STARD group. Towards complete and accurate reporting of studies of diagnostic accuracy: the STARD Initiative. Clin Chem 2003;49:1-6.

3. http://www.consort-statement.org/. Accessed June 2003.

4. Reid MC, Lachs MS, Feinstein AR. Use of methodological standards in diagnostic test research. JAMA 1995;274:645-651.

5. Holloway RG, Feasby T. To test or not to test: that is the question. Neurology 1999;53:1905-1907.

6. Powers WJ. Testing a test: a report card for DWI in acute stroke. Neurology 2000;54:1549-1551.

7. Thornton CA, Welle SL. Molecular fingerprints of inflammatory myopathies. Neurology 2002;59:1128-1129.

8. Bossuyt PM, Reitsma JB, Bruns DE, et al. for the STARD group. The STARD statement for reporting studies of diagnostic accuracy: explanation and elaboration. Ann Intern Med 2003;138:W1-W12.

\section{P WWW.NEUROLOGY.ORG OFFERS VITAL INFORMATION TO PATIENTS AND THEIR FAMILIES}

The Neurology Patient Page provides:

- a critical review of ground-breaking discoveries in neurologic research that are written especially for patients and their families

- up-to-date patient information about many neurologic diseases

- links to additional information resources for neurologic patients.

All Neurology Patient Page articles can be easily downloaded and printed, and may be reproduced to distribute for educational purposes. Click on the Patient Page icon on the home page (www.neurology.org) for a complete index of Patient Pages. 


\section{Neurology}

Improving the flow of diagnostic information: The importance of STARD for authors and readers

Robert G. Holloway

Neurology 2003;61;600-601

DOI 10.1212/01.WNL.0000089443.41909.C7

This information is current as of September 8, 2003

\section{Updated Information \&} Services

References

Citations

Permissions \& Licensing

Reprints including high resolution figures, can be found at: http://n.neurology.org/content/61/5/600.full

This article cites 5 articles, 3 of which you can access for free at: http://n.neurology.org/content/61/5/600.full\#ref-list-1

This article has been cited by 4 HighWire-hosted articles: http://n.neurology.org/content/61/5/600.full\#\#otherarticles

Information about reproducing this article in parts (figures,tables) or in its entirety can be found online at:

http://www.neurology.org/about/about_the_journal\#permissions

Information about ordering reprints can be found online:

http://n.neurology.org/subscribers/advertise

Neurology ${ }^{\circledR}$ is the official journal of the American Academy of Neurology. Published continuously since 1951, it is now a weekly with 48 issues per year. Copyright . All rights reserved. Print ISSN: 0028-3878. Online ISSN: 1526-632X.

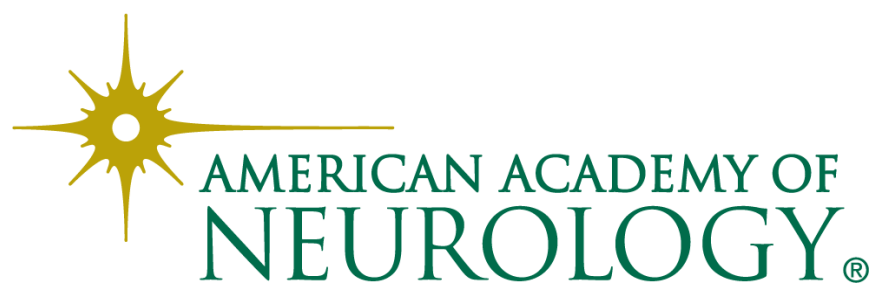

